\title{
O’Shaughnessy Library
}

By GLYDE E. EDDY

Ghortly after his appointMent as head librarian at the College of St. Thomas, the author found himself faced with a reality which had been the big dream and slim hope of his predecessors. Storage boxes and files filled with carefully compiled plans and recommendations for adequate library facilities represented years of planning and designing for the time when a new building would become a reality. It is ironical that these dedicated librarians who had nourished over the years such splendid dreams on such slim hopes for a new building should have accepted other positions by the time the spontaneous and unexpected announcement came on November 9, 1956 of a gift of $\$ 1,800,000$ from Mr. and Mrs. Ignatius A. O'Shaughnessy for a new library building. This librarian had not even had time to form dreams for a new library, much less nurture them, when he was appointed librarian and given the opportunity to help to bring to realization the cherished plans of his predecessors over almost twenty years.

The history of the library of the College of St. Thomas is closely akin to the physical and academic growth of the school. When Archbishop John Ireland founded St. Thomas in 1885, the campus was part of the Finn farm. A single brick building stood atop a knoll near the center of what is now the upper quadrangle of buildings. Nearby woods, rolling hills, peaceful Lake Mennith, and the small creek which ran from the lake into the adjacent Mississippi River comprised the campus for the first sixty-six students.

The library, if it could be called such, was where the student found it-in the rooms of the first professors. Loans were personal ones from personal libraries. Three other buildings were constructed
Reverend Eddy is Librarian, College of St. Thomas, St. Paul, Minn.

before the St. Thomas library got its first real home in the basement of Ireland Residence Hall in 1912. Meanwhile even the supply of books had diminished when St. Paul Seminary was established shortly before the turn of the century and several faculty members were transferred to the Seminary location-taking their books with them.

Dr. Fred Taylor, professor of mathematics and a member of the staff at St. Thomas since 1901, recalls that one of his extra-curricular assignments was that of opening the "library" room in Ireland Hall once a week so that students could take books out for reading. Dr. Taylor chose Sunday mornings and the library was closed during the week.

When Aquinas Hall was built in 1931, a good portion of one wing was set aside for the library. The two-story reference room with connecting periodical room and stacks seemed elegant and adequate for years to come. But as the collection grew, and the influx of veterans following World War II shot the enrollment up to over twenty-two hundred students, the facilities were obviously inadequate. D. R. Watkins, then the librarian, began a series of recommendations to the president urging serious consideration for either expanding the facilities (which was impossible without destroying the architectural beauty of the main quadrangle) or planning an entirely new building. The presidents of St. Thomas were sympathetic, but sympathy does not produce large sums for expansion.

When Mr. O'Shaughnessy, a 1908 alumnus announced his desire to fulfill this dream of St. Thomas, it was singu- 


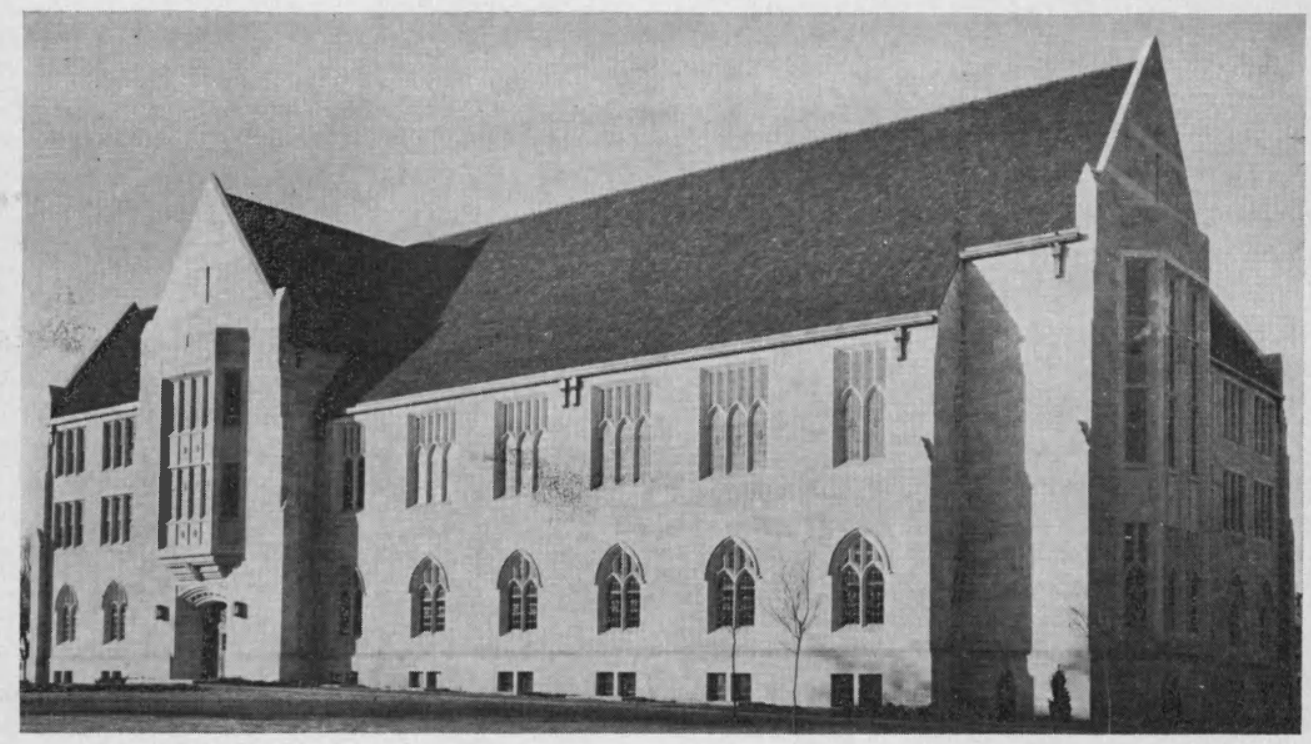

Exterior of the O'Shaughnessy Library

larly significant. A committee headed by Leonard Rogge, director of purchasing and plant operations at St. Thomas and former head librarian of the college, was appointed to bring the hope of years into fruition. Assisting Mr. Rogge were Gertrude Costello, the then acting-librarian; Clara Glenn, St. Thomas Academy librarian; J. Herman Schauinger, professor of history (but also holding a library degree); and H. C. Webb, audio-visual director.

The committee met to compose a description of the ideal library for St. Thomas' needs. The architectural firm of Lange and Raugland who had designed the St. Olaf College Library at Northfield, the St. Paul Seminary Library in St. Paul, and the new Minneapolis Public Library were retained. The first plans and sketches of the committee were submitted to various professional librarians throughout the country, and St. Thomas' faculty members were asked for their recommendations and criticism from departmental standpoints. A fourth set of plans was sent to Keyes Metcalf, librarian emeritus of Harvard College Library, who was retained as professional consultant. At the time of the present librarian's appointment in September 1957, the fifth revision of plans was made and specifications were set. Ground breaking ceremonies occurred in June 1958, and the building was completed in October 1959.

Today O'Shaughnessy Library is an imposing four-story, forty-six room structure-the intellectual heart of the St. Thomas campus. It stands majestically at the eastern end of a quadrangle of buildings dedicated to the tradition of the liberal arts. Its modern Gothic matches the existing structures in the lower quadrangle of buildings, all typified by the use of ribbed vaulting, pointed arches, steep roofs, and exteriors of Mankato limestone.

Mr. O'Shaughnessy had only one suggestion regarding the plans of the library itself-that it would have a large, spacious, inspirational reference room. This idea became the heart of O'Shaughnessy Library-the reference and periodical 
room with a vaulted, oak-paneled ceiling. two-and-one-half stories high, located on the second floor of the building. Immediately adjacent is a foyer with the public catalog and circulation desk. Adjoining this area is a wing which comprises the librarian's suite of offices and the technical processes department. Also on the second floor are a combined work room and staff room, college archives, and lounges.

The library is connected to classroom buildings by a tunnel so that most of the students come to the library via the tunnel and arrive at the basement level of our four-story structure. Here is located a large, unsupervised study hall provided with a small amount of reference materials such as encyclopedias and dictionaries. Also on the basement level are a fully equipped auditorium, capable of seating comfortably 125 persons; an audio-visual center with preview and recording rooms, dark rooms, work and storage areas, and offices; and two seminar rooms, the larger capable of accommodating about forty persons and the smaller about twenty.

The main entrance on the first floor opens into a spacious lobby having a service desk for reserve books. Adjoining is the reserve reading room, equal in area to the second floor reference room but not, of course, having the high vaulted ceiling. On the other side of the lobby is an attractively appointed browsing room which picks up in various ways the numerous features of the reference room -oak paneling, stained-glass medallions in the windows, and smaller versions of the large, impressive chandeliers. Also on the first floor are listening rooms, microfilm rooms, a faculty lounge, and the Celtic library (a special collection in Irish language and literature with approximately four thousand volumes). An appreciated provision on this floor are five comfortable, well equipped private offices for faculty members engaged in writing for publication.
One feature of our library involves the use of a tunnel as an entrance to the library. Students looking for a place for study where they may smoke or talk find it in the basement study hall. Those intending to use reserve books or seeking a quiet place for individual study find this on the first floor in the reserve reading room. Thus it is only the students seeking library materials who make their way to the second floor. The third floor is given over to seminar rooms, a curriculum laboratory, and an art gallery provided with a storage and service room. The library is so designed that all areas in the building except the second floor can be closed in the evenings and on Saturdays and yet complete library service can be given with one librarian and a student assistant.

O'Shaughnessy Library does not have open stacks properly speaking; they perhaps could be called modified open stacks. The stacks are located in a separate wing of eight levels (two tiers to each floor) with the main entrance at the second floor circulation desk. Students have full access to the stacks, but must sign in and out. There are other entrances to the stacks on the first, third, and seventh tiers, opening on the basement, first floor, and third floor respectively. These entrances are locked for the present, but access has been provided for any future change in the use of the library facilities. The stacks will house about two hundred thousand books. (Our present collection has about eighty thousand volumes.) On each tier are to be found seven to ten study and typing carrels. Presently we are using five tiers for our book and periodical collections and two tiers for storage. One tier has been temporarily set up with eight private studies for professors engaged in research. The materials used for the construction of these faculty offices were prefabricated so they can be used again in a different area whenever the library needs that tier for

(Continued on page 304) 
LeMoyne Anderson, Elliott Hardaway, Gustave A. Harrer, Joe H. Howard, Roy L. Kidman, William R. Pullen, and Katherine Walker to the Committee on National Library Week. Mr. Harrer will serve as chairman of this committee.

Frances Kennedy and G. Flint Purdy to the Committee on Organization. Mr. Purdy is the new chairman of this committee.

Dale Barker and Paul Freisner to the Committee on Standards. Mr. Hirsch has accepted reappointment as the chairman of this committee.

Henry C. Koch and Carl Sachtlaben to the Publications Committee. Will Ready has agreed to continue as chairman of this committee.

Mrs. Margaret K. Toth has been reappointed editor of the ACRL Microcard Series. The terms of Maurice F. Tauber as editor of $C R L$ and William V. Jackson as editor of the ACRL Monographs do not expire this year. Mr. Jackson has appointed the following to the editorial board for the Monographs: Donald Coney, Mr. Dunlap, Eileen Thornton, and Stanley West. The composition of the editorial boards for the other ACRL publications is unchanged.

As a special committee, the Advisory Com- mittee To Administer the Burmese projects remains as before: Robert B. Downs, chairman; Paul H. Bixler, William S. Dix, and L. Quincy Mumford.

President Low recently announced the appointment of a special Advisory Committee to the President on Federal Legislation. Mr. Low will serve as chairman of this committee during Mr. Ellsworth's administration. Other members of the commitee are Lewis C. Branscomb, Mr. Downs, Frederick G. Kilgour, Richard H. Logsdon, and Stephen A. McCarthy.

The current Committee on Appointments and Nominations will complete its work at the Cleveland Conference. The new vicepresident and president elect will make his appointments to this committee later in the year.

ACRL's Budget Committee is wholly exofficio, consisting of the division's three principal officers and its executive secretary. Mr. Low will be chairman for 1961-62, and Mark Gormley will replace Mr. Harwell.

Any additional divisional committee appointments will be announced after the Cleveland Conference. Appointments to sectional committees will be made by the new chairmen of the sections later in the year

\section{O'Shaughnessy Library}

(Continued from page 266)

its book collections. There are also located in the stacks a book lift, an elevator, and a depressible receiving book truck for the outside book depository.

There are some special artistic features of O'Shaughnessy Library which should be pointed out. On the outside of the building are to be found carvings of the coats-of-arms of the archbishop and bishops of the diocese. These were prepared by Brioschi Studios of St. Paul. Over the campus entrance is a statue of St. Jerome, patron saint of librarians, sculptured by Joseph Kiselewski of New York. An interesting feature of the building is a series of stained-glass medallions made by Pichel Studios of Waukesha, Wis. Throughout the building these medal- lions, inserted in casement windows, depict various authors, literary figures, the saints of the church, explorers, founders of religious orders, areas of the curriculum, and coats-of-arms.

O'Shaughnessy Library has been in use now for over a year and we have discovered no serious flaw in the over-all plan and operation of our new building. We have found it remarkably adaptable to our changing needs. There have been many willing hands and minds available in the planning of this new library building and St. Thomas is grateful to all of them, but especially the college is profoundly grateful to $\mathrm{Mr}$. O'Shaughnessy who brought to reality this dream of former librarians and presidents. 